\title{
DOI https://doi.org/10.30525/978-9934-26-116-9-34
}

\section{ОБМАН ЯК ОЗНАКА СКЛАДУ КРИМІНАЛЬНОГО ПРАВОПОРУШЕННЯ}

\author{
Сийплокі М. В. \\ доктор юридичних наук, дочент, \\ дочент кафедри кримінального права і прочесу \\ Ужсгородського національного університету \\ м. Ужггород, Україна
}

3 обранням Україною європейського вектору розвитку та початком проведення реформи кримінальної юстиції, відповідно, в державі відбуваються й грунтовні зміни в кримінально-правовій політиці щодо належного забезпечення охорони прав і свобод людини і громадянина, власності, громадського порядку та громадської безпеки, довкілля, конституційного устрою України від кримінально-протиправних посягань, забезпечення миру i безпеки людства, а також запобігання кримінальним правопорушенням [1, с. 282]. Сказане, поза сумнівом, стосується і дослідження такого відносно розповсюдженого кримінально-правового поняття як обман. Обман - це складне i багатогранне кримінально-правове явище, яке здатне універсально трансформуватися в нові склади кримінальних правопорушень.

Аналіз положень Особливої частини Кримінального кодексу України (далі - КК України) в редакції Закону № 1357-IX від 30 березня 2021 року дозволяє зробити висновок, що обман $\epsilon$ обов'язковою ознакою складів багатьох кримінальних правопорушень. В одних із них він прямо передбачений в диспозиціях кримінальноправових норм: незаконне проведення дослідів над людиною (ст. 142), порушення встановленого законом порядку трансплантації анатомічних матеріалів людини (ст. 143), насильницьке донорство (ст. 144), торгівля людьми (ст. 149), перешкоджання здійсненню виборчого права або права брати участь у референдумі, роботі виборчої комісії або комісії референдуму чи діяльності офіційного спостерігача (ст. 157), порушення рівноправності громадян залежно від їх расової, національної належності, релігійних переконань, інвалідності та за іншими ознаками (ст. 161), грубе порушення угоди про працю (ст. 173), шахрайство (ст. 190), заподіяння майнової шкоди шляхом обману або зловживання довірою (ст. 192), втягнення у вчинення терористичного акту (ст. $258^{-1}$ ), проведення видовищного заходу сексуального характеру за участю 
неповнолітньої особи (ст. $301^{-2}$ ), сутенерство або втягнення особи в заняття проституцією (ст. 303), введення в оману суду або іншого уповноваженого органу (ст. 384), ухилення від військової служби шляхом самокалічення або іншим способом (ст. 409).

При тлумаченні інших складів кримінальних правопорушень, обман однозначно виливає 3 ï змісту: незаконне поміщення в заклад 3 надання психіатричної допомоги (ст. 151), надання неправдивих відомостей до органу ведення Державного реєстру виборців або інше несанкціоноване втручання в роботу Державного реєстру виборців (ст. 158), фальсифікація, підроблення, викрадення, пошкодження або знищення виборчої документації, документації референдуму, викрадення, пошкодження, приховування, знищення печатки виборчої комісії, комісії референдуму, виборчої скриньки, списку виборців чи учасників референдуму (ст.158 $8^{-3}$, порушення порядку фінансування політичної партії, передвиборної агітації чи агітації референдуму (ст. $\left.159^{-1}\right)$, викрадення води, електричної або теплової енергії шляхом ії самовільного використання (ст. $188^{-1}$ ), виготовлення, зберігання, придбання, перевезення, пересилання, ввезення в Україну з метою використання при продажу товарів, збуту або збут підроблених грошей, державних цінних паперів, білетів державної лотереї, марок акцизного податку чи голографічних захисних елементів (ст. 199), незаконні дії з документами на переказ, платіжними картками та іншими засобами доступу до банківських рахунків, електронними грошима, обладнанням для їх виготовлення (ст. 200), підроблення документів, які подаються для проведення державної реєстрації юридичної особи та фізичних осіб підприємців (ст. $205^{-1}$ ), протиправне заволодіння майном підприємства, установи, організації (ст. $206^{-2}$ ), незаконне виготовлення, підроблення, використання або збут незаконно виготовлених, одержаних чи підроблених контрольних марок (ст. 216), порушення порядку ведення бази даних про вкладників або порядку формування звітності $\left(\right.$ ст. $\left.220^{-1}\right)$, фальсифікація фінансових документів та звітності фінансової організації, приховування неплатоспроможності фінансової установи або підстав для відкликання (анулювання) ліцензії фінансової установи (ст. 220-2), шахрайство 3 фінансовими ресурсами (ст. 222), маніпулювання на фондовому ринку $\left(222^{-1}\right)$, підроблення документів, які подаються для реєстрації випуску цінних паперів (ст. 223 $3^{-1}$ ), порушення порядку ведення реєстру власників іменних цінних паперів $\left(\right.$ ст. $\left.223^{-2}\right)$, виготовлення, збут та використання підроблених недержавних цінних паперів (ст. 224), умисне введення в обіг на ринку України (випуск на ринок України) небезпечної продукції (ст. 227), незаконне використання інсайдерської інформації (ст. 232 $2^{-1}$ ), 138 
приховування інформації про діяльність емітента (ст. $232^{-2}$ ), приховування або перекручення відомостей про екологічний стан або захворюваність населення (ст. 238), завідомо неправдиве повідомлення про загрозу безпеці громадян, знищення чи пошкодження об'єктів власності (ст. 259), незаконне виготовлення, переробка чи ремонт вогнепальної зброї або фальсифікація, незаконне видалення чи зміна іiі маркування, або незаконне виготовлення бойових припасів, вибухових речовин чи вибухових пристроїв (ст. $263^{-1}$ ), завідомо незаконні затримання, привід, домашній арешт або тримання під вартою (ст. 371), притягнення завідомо невинного до кримінальної відповідальності (ст. 372), незаконне втручання в роботу автоматизованої системи документообігу суд (ст. $376^{-1}$ ), завідомо неправдиве повідомлення про вчинення кримінального правопорушення (ст. 383), представництво в суді без повноважень $\left(400^{-1}\right)$ тощо.

У кожному із перерахованих вище кримінальних правопорушень «обману притаманні індивідуальні риси, що багато в чому обумовлені характером об'єкта й предмета злочину, особливостями суспільно небезпечного діяння (дії чи бездіяльності). Разом із тим, обман у всіх випадках має й загальні риси (ознаки), що властиві всім злочинам, які вчиняються цим способом. Встановлення таких загальних ознак i розробка на цьому підгрунті родового поняття обману має дуже важливе значення для 3'ясування суті, змісту і обсягу обману в кожному конкретному випадку, а також для правильної кваліфікації злочинів, розмежування суміжних злочинів, відмежування злочинних діянь від незлочинних» $[2$, с. $36 ; 3$, с. 7$]$.

3 об'єктивної сторони, обман за своєю суттю $є$ різновидом спілкування («викривленого») між людьми, в якому, з одного боку, виступає особа, яка повідомляє неправдиві, такі що не відповідають дійсності, відомості - обманщик, а з іншого - обманутий, тобто особа, якій спрямовують (адресують) ці відомості. Неправдиві відомості (неправда) при обмані завжди являють собою перекручену інформацію про певні обставини, події, явища, що не відповідає дійсному стану справ та викривляє істину. При обмані винний свідомо фальсифікує інформацію про дійсні відомості (уявлення), про ті чи інші факти реальної дійсності і замість них повідомляє особі, яку обманює, неправдиві відомості в повному або частковому обсязі. При цьому обманщик одночасно приховує, не повідомляє істинні (дійсні) відомості про фактичний стан справ [4, с.72].

Висновки. На підставі викладеного, вважаємо за можливе стверджувати, що кримінально-правове поняття обман $є$ наскрізним. Його ознаки знаходяться в багатьох кримінально-правових нормах 
різних розділів Особливої частини КК України. Спостерігається тенденція до збільшення складів кримінальних правопорушень з ознаками обману в КК України шляхом внесення до нього змін та доповнень. Обман набуває більшої актуальності та суспільної небезпечності в різних сферах суспільних відносинах, які потребують кримінально-правової охорони.

\title{
Література:
}

1. Сийплокі М.В. Особливості об'єктивної сторони притягнення завідомо невинного до кримінальної відповідальності за новим кримінальним процесуальним законодавством України. Електронне наукове фахове видання «Порівняльно-аналітичне право» ДВНЗ «УжНУ». 2014. № 6. С. 282-285.

2. Панов Н.И. Квалификация преступлений, совершаемых путем обмана: учеб.пособ. Х.: Юрид. ин-т, 1980. 88 с.

3. Сабито Р.А. Обман как средство совершения преступления: учеб. пособ. Омск: Омская высшая школа милиции. 1980. 79 с.

4. Панов М. Обман як ознака складу злочину і його кримінальноправове значення. Юридична Україна. 2014. № 5. С. 72-79.

\section{DOI https://doi.org/10.30525/978-9934-26-116-9-35}

\section{КВАЛІФІКАЦІЯ ДІЯННЯ, ВЧИНЕНОГО ОСОБОЮ, ЯКА НЕ Є СУБ'ЄКТОМ КРИМІНАЛЬНОГО ПРАВОПОРУШЕННЯ}

\author{
Ус О. B. \\ доктор юридичних наук, дочент, \\ професор кафедри кримінального права № 1 \\ Начіонального юридичного університету імені Ярослава Мудрого \\ м. Харків, Украӥна
}

Кримінально-правова кваліфікація діяння, що не $є$ кримінально протиправним, проте має кримінально-правове значення, як різновид кваліфікації у кримінальному праві має всі характеристики, що притаманні останній, а також визначається специфічними, видовими ознаками, що характеризують саме ії. Систему таких діянь становлять: діяння, що не володіє кримінально значимим ступенем суспільної 